\title{
Newer agents for Helicobacter pylori eradication
}

This article was published in the following Dove Press journal:

Clinical and Experimental Gastroenterology

16 June 2012

Number of times this article has been viewed

\section{Giulia Fiorini' \\ Angelo Zullo² \\ Luigi Gatta ${ }^{3}$ \\ Valentina Castelli' \\ Chiara Ricci ${ }^{3}$ \\ Francesca Cassol ${ }^{4}$ \\ Dino Vaira' \\ 'Department of Clinical Medicine, University of Bologna, Italy; \\ ${ }^{2}$ Gastroenterology and Digestive \\ Endoscopy, 'Nuovo Regina \\ Margherita' Hospital, Rome, Italy; ${ }^{3}$ Versilia Hospital, Lido di Camaiore, Italy; ${ }^{4}$ School of Gastroenterology, \\ University of Ferrera, Ferrera, Italy}

\begin{abstract}
Helicobacter pylori infection remains widespread internationally, with a definite morbidity and mortality. The efficacy of standard 7-14 day triple therapies is decreasing, mainly due to increasing primary bacterial resistance to antibiotics. Currently, the most effective treatments are either the sequential regimen or the concomitant therapy. Different patents have been registered showing high bactericidal effects in vitro, some of which are active against clarithromycin- and metronidazole-resistant strains, even at low $\mathrm{pH}$ values. Among these novel molecules, benzimidazole-derivatives, polycyclic compounds, pyloricidin, and arylthiazole analogues seem to be the more promising. The identification of essential genes for either bacterial colonization or growth represents a route for potential target therapies in the near future.
\end{abstract}

Keywords: Helicobacter pylori therapy, new antibiotic agents

\section{Introduction}

Despite the evidence that $H$. pylori prevalence is declining in developed countries, the infection remains widespread internationally, with a definite morbidity and mortality. ${ }^{1}$ Indeed, H. pylori is the main cause of nonulcer dyspepsia, peptic ulcer disease, and gastric tumors, including both low-grade mucosa-associated lymphoid tissue lymphoma and adenocarcinoma. ${ }^{2,3}$ Among the extra-digestive diseases, data show a significant association between $H$. pylori infection and both idiopathic thrombocytopenic purpura and idiopathic iron deficiency anemia. ${ }^{4,5} \mathrm{H}$. pylori infection is generally acquired in childhood, and it persists throughout life. Spontaneous resolution is rare, and so a targeted therapy is needed. H. pylori colonizes a kind of biological niche - ie, under the gastric mucous layer, strongly attached to epithelial cells and even within cells - where antibiotic action is impaired, and so, curing such an infection is difficult. Different antibiotic combinations, administered together with a proton pump inhibitor (PPI), have been proposed in the last decades. Unfortunately, no available therapy is able to eradicate $H$. pylori in all treated patients. Therefore, new drugs and novel therapeutic approaches are needed.

\section{Current therapies}

The combination of a PPI with clarithromycin and amoxicillin or metronidazole is the most common first-line therapy regimen. However, current European guidelines confirm the use of standard 7-day triple therapy only in those areas where primary clarithromycin resistance is lower than $15 \%-20 \%$, whilst a prolonged 14-day regimen should be used where bacterial resistance rate is higher. ${ }^{6}$ Nevertheless, data from two large trials found that after completion of the prolonged 14-day triple therapy,
Department of Clinical Medicine University of Bologna, S Orsola Hospital, Via Massarenti 9, 40I 38 Bologna, Italy

Tel +39 5l 6364l40

Fax +3951398794

Email berardino.vaira@unibo.it 
the eradication rate was only $70 \%$ in nonulcer dyspepsia patients, and $81.7 \%$ in peptic ulcer patients. ${ }^{7,8}$ Therefore, different therapeutic approaches are needed. The sequential therapy was first introduced in Italy in $2000 .{ }^{9}$ This regimen is a 10-day therapy, including a simple dual therapy with a PPI plus amoxicillin $1 \mathrm{~g}$ (both twice daily) given for the first 5 days, followed by a triple therapy including a PPI, clarithromycin $500 \mathrm{mg}$, and tinidazole $500 \mathrm{mg}$ (all given twice daily) for the remaining 5 days.

The first comprehensive, pooled-data analysis of sequential therapy, which included over 1,800 Italian patients, found an eradication rate as high as $93.5 \% .{ }^{10}$ Moreover, the high efficacy of such a therapy regimen has been confirmed in several other countries, including Israel, Korea, Panama, Poland, Romania, Spain, Taiwan and Thailand, but not in Iran or Latin America. ${ }^{11-17}$ Different trials compared the efficacy of sequential therapy with that of standard triple therapies. A meta-analysis showed that a sequential regimen was better than standard 7-10 day triple therapies. ${ }^{18}$ These data have been updated, and the eradication rates following the sequential therapy $(2,454 / 2,853 ; 86 \% ; 95 \%$ CI: 84.7-87.3) remained distinctly higher compared to that of triple therapies $\left(2,320 / 3,079 ; 75.3 \%\right.$; 95\% CI: 73.8-76.9). ${ }^{19}$

Some recent studies found that a levofloxacin- instead of clarithromycin-based sequential therapy also appears highly effective. ${ }^{20,21}$ However, such modified sequential therapy precludes the use of a levofloxacin-based second-line therapy, thereby complicating any successive therapeutic approach in patients who fail eradication therapy. ${ }^{22,23}$ Moreover, primary resistance to levofloxacin is quickly increasing worldwide, with prevalence values of 17\% in Brazil, 16.8\% in Belgium, $22.1 \%$ in Germany, $18 \%$ in Hong Kong, $19.1 \%$ in Italy, $14.3 \%$ in Japan, and $21.5 \%$ in Korea. ${ }^{22}$ Therefore, levofloxacin should be used with caution in a first-line therapy regimen. ${ }^{24}$

Concomitant therapy comprises a PPI plus amoxicillin, clarithromycin, and metronidazole, given all together. This therapy was first introduced as an alternative to standard triple therapies more than 10 years ago, and the original duration of therapy was only 5 days. A recent meta-analysis of 15 studies found a high efficacy of this regimen, with an eradication rate of $90 \%$. However, it was noted that the eradication rate increased with therapy duration, being $85 \%$ at 3 days, $88 \%$ at 4 days, $89 \%$ at 5 days, $93 \%$ at 7 days, and $92 \%$ at 10 days. ${ }^{25}$ Another meta-analysis of 9 studies including only 7-day concomitant therapy calculated eradication rates of $90 \%$ at ITT and $93 \%$ at PP analysis. ${ }^{26}$ Pooled estimates of the five randomized controlled trials showed the superiority of concomitant therapy over triple therapy (OR: 2.86; 95\% CI: $1.73-4.73) .{ }^{26}$

\section{Future therapies}

Although the contributing factors differ, ${ }^{27}$ therapy failure mainly depends on primary resistance to different antibiotics (eg, clarithromycin), which is increasing worldwide. ${ }^{28}$ It is thought that only new classes of antimicrobials with novel mechanisms of action can fully address the increasing drug resistance. ${ }^{29}$ In the last decade, several patents of new antibiotics have claimed potential activity against $H$. pylori. ${ }^{30-32}$ Of note, some molecules have shown a very high bactericidal level of activity against $H$. pylori in vitro, including those strains with primary clarithromycin and/or metronidazole resistance. In addition, some molecules preserve antibacterial activity even at low $\mathrm{pH}$ values, a clear advantage for $H$. pylori treatment, considering that they must act in gastric acid. In particular, different benzimidazole-derivatives and polycyclic compounds have been patented, which are highly effective against $H$. pylori. ${ }^{30}$ Pyloricidin A, B, and $\mathrm{C}-\mathrm{a}$ family of natural antibiotics - have exhibited a potent and highly selective bactericidal activity against $H$. pylori, with an $\mathrm{MIC}_{90}$ value of $0.013 \mathrm{mg} / \mathrm{L} .{ }^{30} \mathrm{In}$ addition, among the arylthiazole analogues, the thienylthiazole derivative 44 exhibited the strongest activity, with $\mathrm{MIC}_{90}$ values as low as $0.0065 \mathrm{mg} / \mathrm{L} .{ }^{30}$ Of note, some isothiazole derivatives have been found to enable a potent inhibition of bacterial urease activity in vitro, constituting a potential "targeted" therapy for H. pylori infection. ${ }^{31}$ The list of potential useful molecules is provided in Table 1, while in Table 2 there are several plant extracts with anti- $H$. pylori activity in vitro. ${ }^{30-34}$ Therefore, it is likely that more powerful drugs will be available in the near future to treat $H$. pylori infection.

Table I New molecules with $H$. pylori activity

\begin{tabular}{llll}
\hline Molecule & $\begin{array}{l}\text { MIC } \\
(\mathbf{m g} / \mathbf{L})\end{array}$ & $\begin{array}{l}\mathbf{p H} \\
\text { activity }\end{array}$ & $\begin{array}{l}\text { Cla-R/ } \\
\text { Met-R }\end{array}$ \\
\hline $\begin{array}{l}\text { Arylthiazole derivative 44 } \\
\text { Benzimidazole derivatives }\end{array}$ & 0.0065 & $\mathrm{NA}$ & $\mathrm{NA} / \mathrm{NA}$ \\
$\quad$ Y-754 & 0.025 & 5.5 & $\mathrm{NA} / \mathrm{NA}$ \\
$\quad$ BAS-II8 & 0.013 & $\mathrm{NA}$ & Yes/yes \\
I-valnemulin & $0.0125-0.5$ & $\mathrm{NA}$ & Yes/yes \\
Mupirocin & $0.12-0.25$ & 5.4 & $\mathrm{NA} / \mathrm{NA}$ \\
Polycyclic compound & $0.2-0.39$ & $\mathrm{NA}$ & $\mathrm{NA} / \mathrm{NA}$ \\
Pyloricidin (A, B, and C) & 0.013 & $\mathrm{NA}$ & $\mathrm{NA} / \mathrm{NA}$ \\
Rifampin & $0.032-2$ & $\mathrm{NA}$ & Yes/yes \\
\hline
\end{tabular}

Notes: $\mathrm{MIC}_{90}$ : minimal inhibitory concentration; Cla-R: efficacy towards clarithromycin resistant strains; Met-R: efficacy towards metronidazole resistant strains.

Abbreviation: NA, not available. 
Table 2 Some plant extracts with potential anti-H. pylori activity in vitro

\begin{tabular}{lll}
\hline Plant source & Source or molecule & MIC $_{90}(\mathbf{m g} / \mathbf{L})$ \\
\hline Barringtonia acutangola & Leaf & 25 \\
Cassia grandis & Leaf & 50 \\
Cleome viscosa & Leaf & 50 \\
Cycas siamensis & Leaf & 100 \\
Hypericum perforatum & L. Hyperforin & $15.6-31.2$ \\
Hyptis fasciculata & Cirsilineol/Cirsimaritin & $3.2-6.3$ \\
Kaempferia galanga & Rhizome & 25 \\
Litsea elliptica & Leaf & 100 \\
Maleleuca quinquenervia & Leaf & 100 \\
Mallotus philippinensis & Rottlerin & $3.12-6.25$ \\
Myristica fragrans & Aril & 12.5 \\
Myristica fragrans & Leaf & 50 \\
Pistacia lentiscus & Triterpenic acids & 0.139 \\
Pouzolzia pentandra & Leaf & 100 \\
Syzygium aromaticum & Leaf & 50 \\
Vitis vinifera & Resveratrol & $6-12.5$ \\
Xanthium brasilicum & Xanthanolide & $13.2-250$ \\
Zingiber officinale & Rhizome & $0.78-12.5$ \\
\hline A &
\end{tabular}

Abbreviation: $\mathrm{MIC}_{90}$, minimal inhibitory concentration.

Many studies have addressed the identification of novel therapeutic targets (eg, bacterial proteins, mechanisms, genes required for growth and/or colonization, etc). Further investigation of anti-H. pylori therapies have addressed the identification of essential genes required for in vitro bacterial survival, or genes essential for mucosal colonization. . $^{35,36}$ Indeed, several studies have shown large numbers of genes involved in cellular motility that are required for colonization or growth, demonstrating that they represent a potential target by $H$. pylori-specific anti-infective agents. Additional functions potentially susceptible to therapeutic intervention include cellular processes like chemotaxis, protein folding, regulation, genetic information processing, and resistance to acid and oxidative stresses. ${ }^{37}$ There are several genes that have been evaluated as potential therapeutic targets, most of them encoded for proteins which form biochemical pathways, or urease-related genes that are essential for host colonization. There are also many gene-encoding proteins required for bacterial growth that have been studied as potential therapeutic targets, but further evaluations are needed. ${ }^{38}$

\section{Conclusion}

The available antibiotics active against $H$. pylori in vivo are very rare, and new molecules are needed. The current most effective combination of these drugs is both sequential and concomitant therapy. Different patents have been registered showing high bactericidal effects in vitro, some of which are active against clarithromycin- and metronidazole-resistant strains, even at low $\mathrm{pH}$ values. Therefore, the search for novel antibacterial therapies against $H$. pylori is a "work in progress" driven by the goal of preventing gastric cancer, and by worldwide increasing antibiotic resistance.

\section{Disclosure}

The authors reports no conflicts of interest in this work.

\section{References}

1. Sonnenberg A, Lash RH, Genta RM. National study of Helicobacter pylori infection in gastric biopsy specimens. Gastroenterology. 2010;139(6): 1894-1901.

2. Alakkari A, Zullo A, O'Connor HJ. Helicobacter pylori and nonmalignant diseases. Helicobacter. 2011;16 Suppl 1:33-37.

3. Zullo A, Hassan C, Cristofari F, et al. Effects of Helicobacter pylori eradication on early stage gastric mucosa-associated lymphoid tissue lymphoma. Clin Gastroenterol Hepatol. 2010;8(2):105-110.

4. Stasi R, Sarpatwari A, Segal JB, et al. Effects of eradication of Helicobacter pylori infection in patients with immune thrombocytopenic purpura: a systematic review. Blood. 2009;113(6): $1231-1240$

5. Huang X, Qu X, Yan W, et al. Iron deficiency anemia can be improved after eradication of Helicobacter pylori. Postgrad Med J. 2010;86(1015):272-278.

6. Malfertheiner P, Megraud F, O'Morain C, et al. Current concepts in the management of Helicobacter pylori infection: the Maastricht III Consensus Report. Gut. 2007;56(6):772-781.

7. Zagari RM, Bianchi-Porro G, Fiocca R, et al. Comparison of 1 and 2 weeks of omeprazole, amoxicillin and clarithromycin treatment for Helicobacter pylori eradication: the HYPER Study. Gut. 2007;56(4): 475-479.

8. Paoluzi P, Iacopini F, Crispino P, et al. 2-week triple therapy for Helicobacter pylori infection is better than 1-week in clinical practice: a large prospective single-center randomized study. Helicobacter. 2006;11(6):562-568.

9. Zullo A, Rinaldi V, Winn S, et al. A new highly effective shortterm therapy schedule for Helicobacter pylori eradication. Aliment Pharmacol Ther. 2000;14(6):715-718.

10. Zullo A, De Francesco V, Hassan C, Morini S, Vaira D. The sequential therapy regimen for Helicobacter pylori eradication: a pooled-data analysis. Gut. 2007;56(10):1353-1357.

11. Vaira D, Zullo A, Hassan C, Fiorini A, Vakil N. Sequential Therapy for Helicobacter pylori Eradication: The Time Is Now! Therap Adv Gastroenterol. 2009;2(6):317-322.

12. Kwon JH, Lee DH, Song BJ, et al. Ten-day sequential therapy as firstline treatment for Helicobacter pylori infection in Korea: a retrospective study. Helicobacter. 2010;15(2):148-153.

13. Sirimontaporn N, Thong-Ngam D, Tumwasorn S, Mahachai V. Ten-day sequential therapy of Helicobacter pylori infection in Thailand. Am J Gastroenterol. 2010;105(5):1071-1075.

14. Schmilovitz-Weiss H, Shalev T, Chechoulin Y, et al. High eradication rates of Helicobacter pylori infection following sequential therapy: the Israeli experience treating naïve patients. Helicobacter. 2011;16(3):229-233.

15. Wu DC, Hsu PI, Wu JY, et al. Sequential and concomitant therapy with four drugs is equally effective for eradication of $\mathrm{H}$. pylori infection. Clin Gastroenterol Hepatol. 2010;8(1):36-41.

16. Greenberg ER, Anderson GL, Morgan DR, et al. 14-day triple, 5-day concomitant, and 10-day sequential therapies for Helicobacter pylori infection in seven Latin American sites: a randomised trial. Lancet. 2011;378(9790):507-514.

17. Aminian K, Farsad F, Ghanbari A, Fakhreih S, Hasheminasab SM. A randomized trial comparing four Helicobacter pylori eradication regimens: standard triple therapy, ciprofloxacin based triple therapy, quadruple and sequential therapy. Trop Gastroenterol. 2010;31(4): 303-307. 
18. Jafri NS, Hornung CA, Howden CW. Meta-analysis: sequential therapy appears superior to standard therapy for Helicobacter pylori infection in patients naive to treatment. Ann Intern Med. 2008;148(12):923-931.

19. Gatta L, Vakil N, Leandro G, Di Mario F, Vaira D. Sequential therapy or triple therapy for Helicobacter pylori infection: systematic review and meta-analysis of randomized controlled trials in adults and children. Am J Gastroenterol. 2009;104(12):3069-3079.

20. Romano M, Cuomo A, Gravina AG, et al. Empirical levofloxacincontaining versus clarithromycin-containing sequential therapy for Helicobacter pylori eradication: a randomised trial. Gut. 2010;59(11): 1465-1470.

21. Molina-Infante J, Perez-Gallardo B, Fernandez-Bermejo M, et al. Clinical trial: clarithromycin vs levofloxacin in first-line triple and sequential regimens for Helicobacter pylori eradication. Aliment Pharmacol Ther. 2010;31(10):1077-1084.

22. Zullo A, Hassan C, D'Ercole C, D Francesco V, Vaira D. Clarithromycin or levofloxacin in the sequential therapy for $H$. pylori eradication? Aliment Pharmacol Ther. 2010;31(11):1248-1249.

23. Zullo A, De Francesco V, Vaira D. Sequential therapy for Helicobacter pylori eradication: is levofloxacin better? Gut. 2011;60(11):1604.

24. Berning M, Krasz S, Miehlke S. Should quinolones come first in Helicobacter pylori therapy? Therap Adv Gastroenterol. 2011;4(2): 103-114.

25. Essa AS, Kramer JR, Graham DY, Treiber G. Meta-analysis: fourdrug, three-antibiotic, non-bismuth-containing "concomitant therapy" versus triple therapy for Helicobacter pylori eradication. Helicobacter. 2009;14(2):109-118.

26. Gisbert JP, Calvet X. Review article: non-bismuth quadruple (concomitant) therapy for eradication of Helicobater pylori. Aliment Pharmacol Ther. 2011;34(6):604-617.

27. Zullo A, De Francesco V, Hassan C. Predicting Helicobacter pylori Eradication: How to Teach an Old Dog New Tricks! J Clin Gastroenterol. 2012;46(4):259-261.
28. De Francesco V, Giorgio F, Hassan C, et al. Worldwide H. pylori antibiotic resistance: a systematic review. J Gastrointestinal Liver Dis. 2010;19(4):409-414.

29. Spellberg B, Powers JH, Brass EP, Miller LG, Edwards JE Jr. Trends in antimicrobial drug development: implications for the future. Clin Infect Dis. 2004;38(9):1279-1286.

30. Zullo A, Hassan C, Campo SMA, Morini S. Evolving therapy for Helicobacter pylori infection. Exp Opin Ther Patents. 2004;14(10): 1453-1464.

31. Zullo A, Hassan C, Eramo A, Morini S. Helicobacter pylori therapy: what is coming? Expert Opin Ther Patents. 2006;16(8): 1107-1112.

32. Campo SM, Zullo A, Hassan C, Morini S. Antibiotic treatment strategies for Helicobacter pylori infection. Recent Pat on AntiInfect Drug Discov. 2007;2(1):11-17.

33. Kamiji MM, de Oliveira RB. Non-antibiotic therapies for Helicobacter pylori infection. Eur J Gastroenterol Hepatol. 2005;17(9):973-981.

34. Ito $\mathrm{H}$, Yazawa $\mathrm{S}$, Nishiyama $\mathrm{T}$, Nonaka $\mathrm{M}$. In vitro inhibition of Helicobacter pylori by several dietary plant agents. Int J Antimicrob Agents. 2008;32(1):89-98.

35. Salama NR, Shepherd B, Falkow S. Global transposon mutagenesis and essential gene analysis of Helicobacter pylori. J Bacteriol. 2004;186(23):7926-7935.

36. Chalker AF, Minehart HW, Hughes NJ, et al. Systematic identification of selective essential genes in Helicobacter pylori by genome prioritization and allelic replacement mutagenesis. J Bacteriol. 2001; 183(4):1259-1268.

37. Baldwin DN, Shepherd B, Kraemer P, et al. Identification of H. pylori genes contributing to stomach colonization. Infect Immun. 2007;75(2): 1005-1016.

38. Kavermann H, Burns BP, Angermuller K, et al. Identification and characterization of Helicobacter pylori genes essential for gastric colonization. J Exp Med. 2003;197(7):813-822.
Clinical and Experimental Gastroenterology

\section{Publish your work in this journal}

Clinical and Experimental Gastroenterology is an international, peerreviewed, open access journal, publishing all aspects of gastroenterology in the clinic and laboratory, including: Pathology, pathophysiology of gastrointestinal disease; Investigation and treatment of gastointestinal disease; Pharmacology of drugs used in the alimentary tract;

\section{Dovepress}

Immunology/genetics/genomics related to gastrointestinal disease. This journal is indexed on CAS. The manuscript management system is completely online and includes a very quick and fair peer-review system. Visit http://www.dovepress.com/testimonials.php to read real quotes from published authors. 